\title{
Suitability of pure nanocrystalline LiF as a TLD dosimeters for high dose gamma
} radiation

\author{
H. Amer ${ }^{1 *}$, M. El Ashmawy, H. Al Azab ${ }^{2}$, M. R. Ezz El-Din. \\ Nuclear and Radiological Regulatory Authority, 3-Ahmed El-Zomor Street, El-Zohour \\ District, Nasr City, 11762 Cairo, Egypt.
}

\begin{abstract}
$\mathrm{LiF}$ is an alkali halide that is commonly used in radiation dosimetry utilizing its well known thermoluminescence property. Pure LiF has very limited use in radiation dosimetry since the density and types of the internal traps are limited. For that reason, LiF usually are doped with different elements such as Mg and Ti in (TLD-100) to enhance its TL properties and to be suitable for dosimetry applications. In this work we used ball milling as an alternative to dopants (impurities) to induce structure defects (e.g. dislocation) that will play the major role in TL process instead to dopants. A pristine LiF was milled for 1 hour and compressed in form of chips then annealed for $1 \mathrm{~h}$ at $600{ }^{\circ} \mathrm{C}$ to get rid of low temperature dislocations. The annealed samples showed linear response in the range 50-300 Gy. Fading investigation showed that the overall integral TL intensity almost stabilizes after 12 day from first irradiation. The study indicates that ball milling is new promising technique to produce TL dosimeters free of dopants.
\end{abstract}

\section{Kyewords}

Thermoluminescence, LiF, glow curve, ball milling, dislocation, synchrotron radiation, dose response, fading.

\section{Introduction}

Thermoluminescence is the emission of light from an insulator or semiconductor when it is heated. The crystalline forms of some inorganic phosphors store some of the energy imparted to them from ionizing radiation and release that energy as light when the temperature of the crystal is raised. TL phenomenon of Thermoluminescence is a complex process and many kinetic models have been proposed in literature discussing various TL mechanisms (Chen \&McKeever 1997; Kirsh, 1992). A simplified explanation could be introduced on basis of the one trap one recombination centre (OTOR) model shown in figure (1). In OTOR, the TL material has two kinds of metastable states in the wide forbidden gap between the valence and

* Corresponding Author: hanyamer11@gmail.com 
the conduction bands. These metastable states are introduced either by adding some chemical impurities or by introducing structural defects in the lattice. One of such states exists near the conduction band and acts as a trap for electrons while the other exists near the valence band and acts as a trap for holes. When the TL material is excited by radiation, pairs of electron / hole are generated and are ultimately captured in their respective traps (figure (1) left).

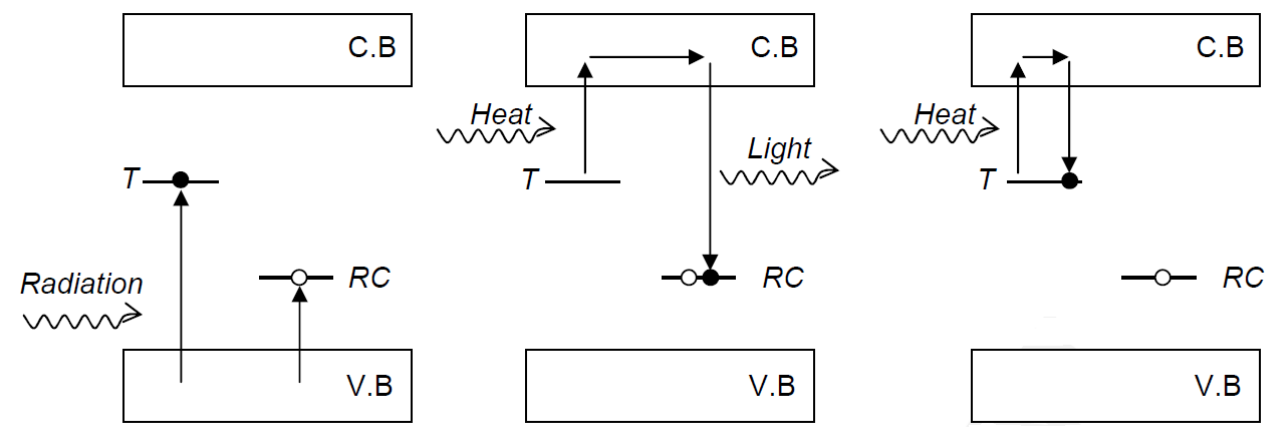

Figure (1) OTOR model

When the TL material is heated up to appropriate temperatures, the electrons are thermally released to the conduction band and such electrons have two possible pathways. The first one is to recombine directly with the trapped holes yielding emitted light (figure (1) middle); for that reason the metastable state that captures the holes is called recombination centre (RC) and the metastable state that captures electrons is called a trap (T). The other pathway for the released electrons is to be retrapped again by the electron traps (figure (1) right) before they thermally released again to recombine with respective holes at $\mathrm{RC}$; the process in this case could be simply defined as indirect recombination. The energy required to release the electron from its trap to the conduction band called activation energy. The relationship between the temperature and the intensity of the released light is known as "glow curve" and could be composed of a single or multiple superimposed TL glow peaks and each glow peak corresponds to specific trap i.e. specific activation energy, more details will be presented in next section.

In early 1950s, the TL phosphors used in present day dosimetery were discovered. These included LiF by (Daniels; 1965) which the most commonly used TL materials. LiF-based thermoluminscent (TL) materials are widely used as a personal dosimetric material because of their low energy dependence, high sensitivity, stability and tissue equivalency. The use of pure LiF is limited in dosimetry field so the scientists go to adding some impurity to the pure LiF crystal to use it as a dosimeter. The Thermoluminscent dosimetry (TLD) material based 
on $\mathrm{LiF}$ that has been studied most extensively is $\mathrm{LiF}: \mathrm{Mg}$, Ti which is widely used in personal dosimetry and available in the market under trade names TLD- 100 (Vij; 1993). Another TL phosphor material LiF: $\mathrm{Mg}, \mathrm{Cu}, \mathrm{P}$ shows very favorable dosimetric characteristics with great potential applications for low level dose measurements in the field of diagnostic radiology. This TL phosphor in powder form was first introduced by Nakajima et al.; 1978. Several authors studied and modified its characteristics (Chandra et al., 1982; DeWerd et al., 1984; Wu et al. 1984). Heating and cooling rate, readout and annealing temperatures which could greatly affect the dosimetric performance of LiF: $\mathrm{Mg}, \mathrm{Cu}, \mathrm{P}$. Residual dose in the phosphor after readout has also been a major problem for dosimetric work. Bacci et al.; 1993 tried to identify the optimal annealing cycle for LiF: Mg. Cu, P, and Pradhan; 1995 did detailed experiments on the effect of heating rate on the TL response.

There are many methods to create structural defects in materials; however ball milling is a very powerful technique that can introduce structural defects in materials. Plastic deformation (i.e. dislocations) is the most common and probable defect type for ball milling as a result of the energetic impacts between powder, vial and balls. In the present work, we prepared LiF (LiF was selected to perform this analysis because of its well-known TL properties as well as its quite simple crystal structure) crystal using ball-milling way to introduce dislocation instead of dopant.

\section{Materials and Methods}

\subsection{Sample Preparation}

$2 \mathrm{~g}$ of commercially available LiF (99.99\% from Sigma Aldrich) was ground in a planetary ball milling (Fritsch Pulverisette 6) machine operating at high rotational speed (700 rpm). The pristine (as received) LiF powder was ball milled for one hour in $80 \mathrm{ml}$ agates container. Twenty balls, made of agate, with $1 \mathrm{~cm}$ diameter were used. The milled LiF powder are then compressed in the form of discs with diameter of $3 \mathrm{~mm}$ and each disk weights $5 \mathrm{mg}$ approximately. About 500 disks were prepared and distributed on a glass substrate. The disks were subjected to temperature rate of $10^{\circ} \mathrm{C} / \mathrm{min}$ and heated up to $600^{\circ} \mathrm{C}$ and annealed at this temperature for 1 hour. The samples are then taken and quenched in the room temperature. About 340 samples were collected in good conditions.

The samples were irradiated by high energy gamma radiation. The ${ }^{60} \mathrm{Co} \gamma$-rays cell model $\gamma$-cell-220. The LiF samples are placed inside the $\gamma$-cell chamber in such a way that all samples exposed to the same dose. The TL glow curves of the samples were measured by using a Harshow model 4500 TLD reader with different linear heating rates in temperature range from $50^{\circ} \mathrm{C}$ to $600^{\circ} \mathrm{C}$. 


\subsection{Samples characterization}

\subsubsection{X-ray powder diffraction (XRPD)}

Microstructural characterization of the LiF samples was carried out at the (Microstructural characterization X-Ray beamline) MCX beamline (Rebuffi et al., 2014) of the Italian Synchrotron ELETTRA (Trieste). The measurements were carried out at the photon energy (12 keV) using Debye-Scherrer geometry. This setup was used to perform fine microstructure line profile analysis at room temperature. A standard sample of NIST SRM 640a silicon in a borosilicate capillary ( $0.3 \mathrm{~mm}$ in diameter) was used to define the instrumental resolution to be considered in the analysis. Then, each sample was prepared in the borosilicate capillary ( $0.3 \mathrm{~mm}$ in diameter). Diffraction data were collected in the range $15-75^{\circ} 2 \theta$ in steps of $0.01^{\circ}$. The refined wavelength obtained from the Si standard pattern measured by the MCX diffractometer was $1.03231 \AA$.

The microstructure was analysed using the whole powder pattern modelling (WPPM) approach (Scardi \& Leoni, 2002, 2004) through the PM2K program (Leoni et al., 2006). In the modelling, the instrumental profile parameters were fixed and then the line profiles were modelled by considering the crystal size and the lattice strain in terms of dislocations where both aforementioned parameters are the main structural sources of broadening. The crystal size was modelled as spherical crystals of lognormal distribution with two refinable parameters, namely mean $\mu$ and variance $\sigma$. Equation (1) shows the dislocation average contrast factors A and B for cubic crystals,

$C_{\text {average }}=A+B \frac{h^{2} k^{2}+k^{2} l^{2}+h^{2} l^{2}}{\left(h^{2}+k^{2}+l^{2}\right)^{2}}$

This equation takes into account the anisotropic broadening caused by dislocations as a function of $h k l$ planes. The value of the contrast factor A was calculated analytically $\left(\mathrm{A}_{\text {edge }}=\right.$ $\left.0.195, \mathrm{~A}_{\text {screw }}=0.162, \mathrm{~A}_{\text {average }}=0.179\right)$ as proposed by Ungár et al. (1999) and then the parameter $\mathrm{B}$, dislocation density $\rho$ and the average cut-off radius $\mathrm{R}_{\mathrm{eff}}\left(\mathrm{R}_{\mathrm{eff}}\right.$ is the effective cutoff radius of the dislocation) were left as free refinable parameters in the strain model. Beside the crystal size and the lattice strain models, a Chebychev polynomial function with refined coefficients was used to fit the background of the diffraction patterns.

\subsubsection{XRPD analysis}

For pulverized LiF, the one-phase WPPM model was sufficient and stable to fit the collected diffraction patterns, which relates to the samples' homogeneity. Starting from the pristine LiF powder, large crystallite sizes of about $500 \mathrm{~nm}$ coupled with an absence of 
dislocations were observed. After 1h of milling, a strong decrease in the crystal size down to 36 (8) $\mathrm{nm}$ was observed, and the dislocation density was found to be about $4.4(2) \times 10^{15} \mathrm{~m}^{-2}$.

According to WPPM theory (Scardi \& Leoni, 2002, 2004), the Wilkens factor (Wilkens, 1970) $\mathrm{M}\left[\mathrm{M}=\operatorname{Re}\left(\rho^{1 / 2}\right)\right]$ refers to the interactions among dislocations, where smaller $\mathrm{M}$ means a larger interaction is likely to take place at the crystal boundaries, and vice versa. The $\mathrm{M}$ values after $1 \mathrm{~h}$ of milling were slightly above 1. Figure (2) shows the WPPM fitting of the annealed LiF sample diffraction pattern as a witness of fitting quality.

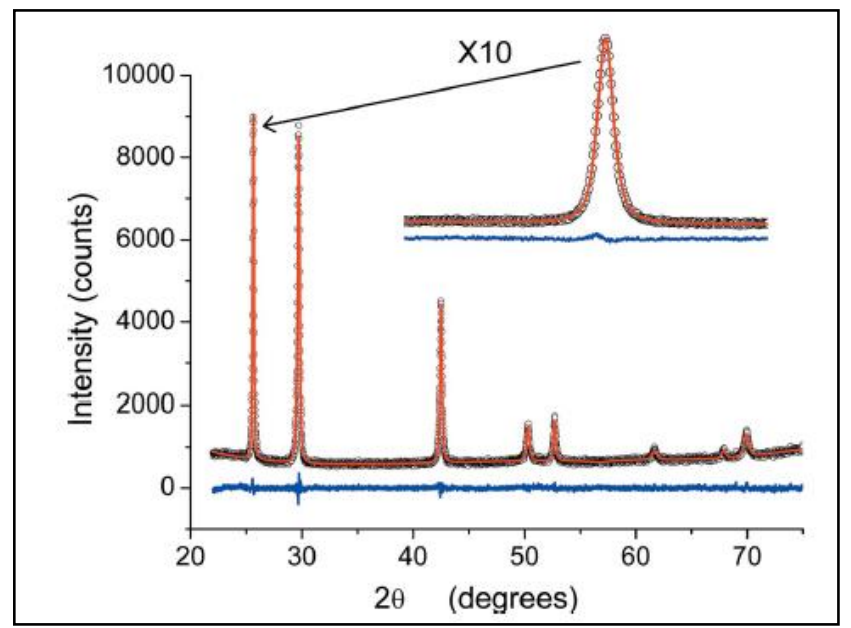

Figure (2) WPPM fitting for the LiF annealed sample. The inset shows the fitting quality of the (111) crystalline plane zoomed in ten times. The open circles refer to the raw data; the continuous line refers to the fitting model and the line below refers to the residual.

\section{Results and Discussion}

\subsection{GAMMA-DOSE RESPONSE MEASUREMENT}

The usual method for studying the response of TL as a function of irradiation dose is to irradiate the TL materials at constant dose rate, constant temperature, and then to read out the TL materials (Rasheedy and Amry, 1994).

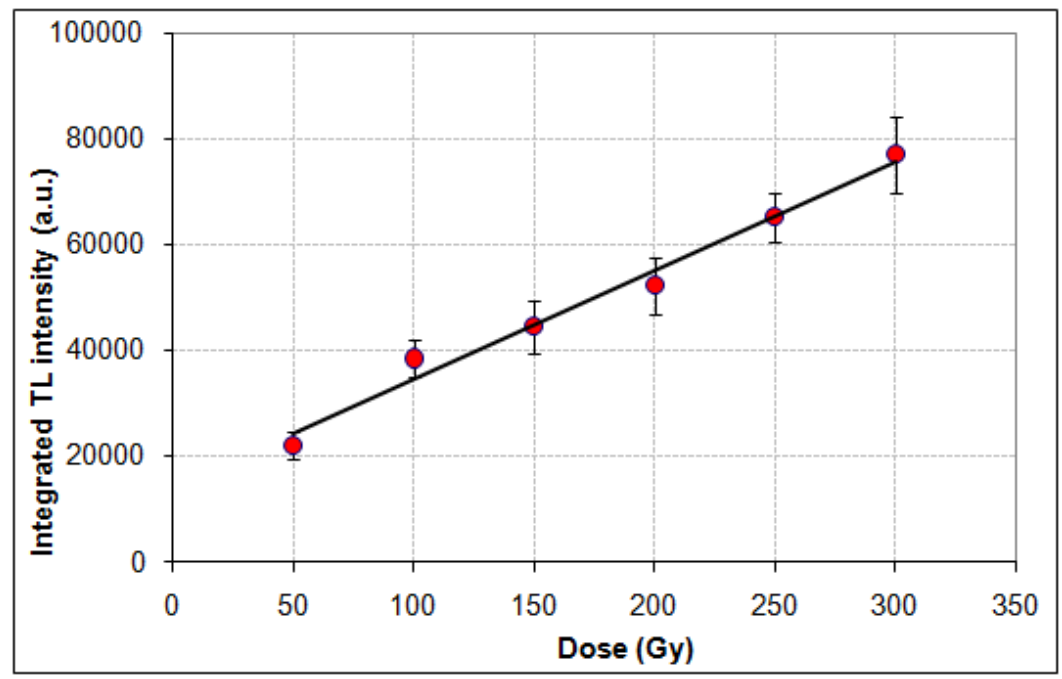


Figure (3) Thermoluminescence intensity as a function of $\gamma$ - absorbed dose $\left({ }^{60} \mathrm{Co}\right.$-source) for $\mathrm{LiF}$, vertical bars represented the standard deviation at each dose.

In the present work, the irradiation is carried at room temperature. The chips were irradiated at 50,100,150, 200, 250, 300 Gy. The TL response of each chip was measured at $5 \mathrm{~K} / \mathrm{sec}$ heating rate to reveal the glow peaks of the glow curve as it will be shown soon. 7-9 disks were used for each dose for the purpose of reliable statistics. The response of $\mathrm{LiF}$ caused by the irradiation is taking to be the integral over the whole glow curve. Figure (3) represents the integrated TL intensity as a function of irradiation dose. As depicted, the prepared TL samples have linear TL response as the irradiation dose increases up to $300 \mathrm{~Gy}$.

Figure (4) represents glow curves over the dose range 50Gy to 300Gy, as shown, the glow curve has 4 prominent peaks at fixed positions and their amplitudes are increasing as the dose increase.

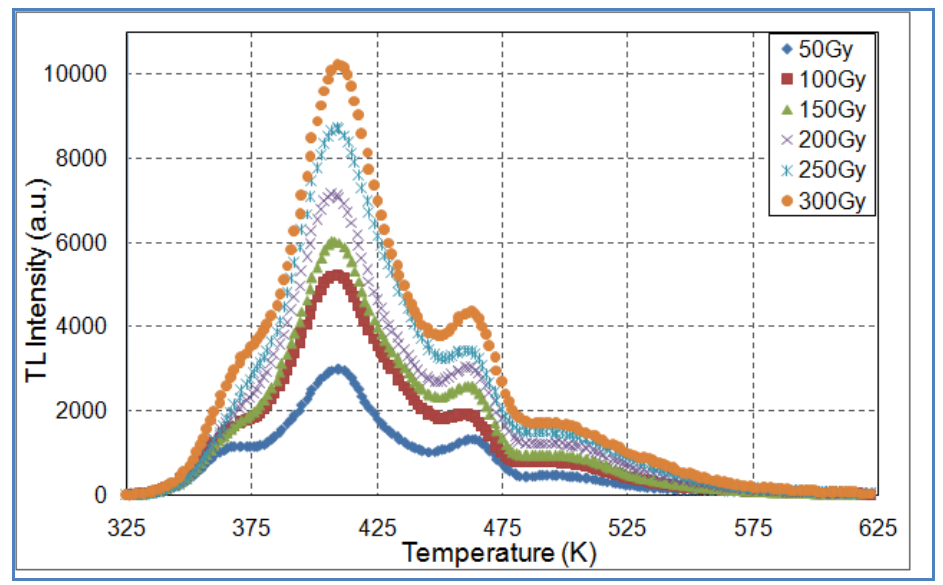

Figure (4) presents the variations of the glow curves over the dose range from 50 Gy to $300 G y$.

\subsection{HEATING RATES}

Several disks have been measured at different heating rates, namely $2,5,7,10,13,15,17$, $20,22,25 \mathrm{Ks}^{-1}$. The results show that there is an increase in the TL intensity as the heating rate increases as shown in figure (5). Again 7-9 chips were measured for each heating rate and then the standard deviation were calculated and represented by vertical bars in figure (5). It has been found that the relation between heating rates and TL response is linear. 


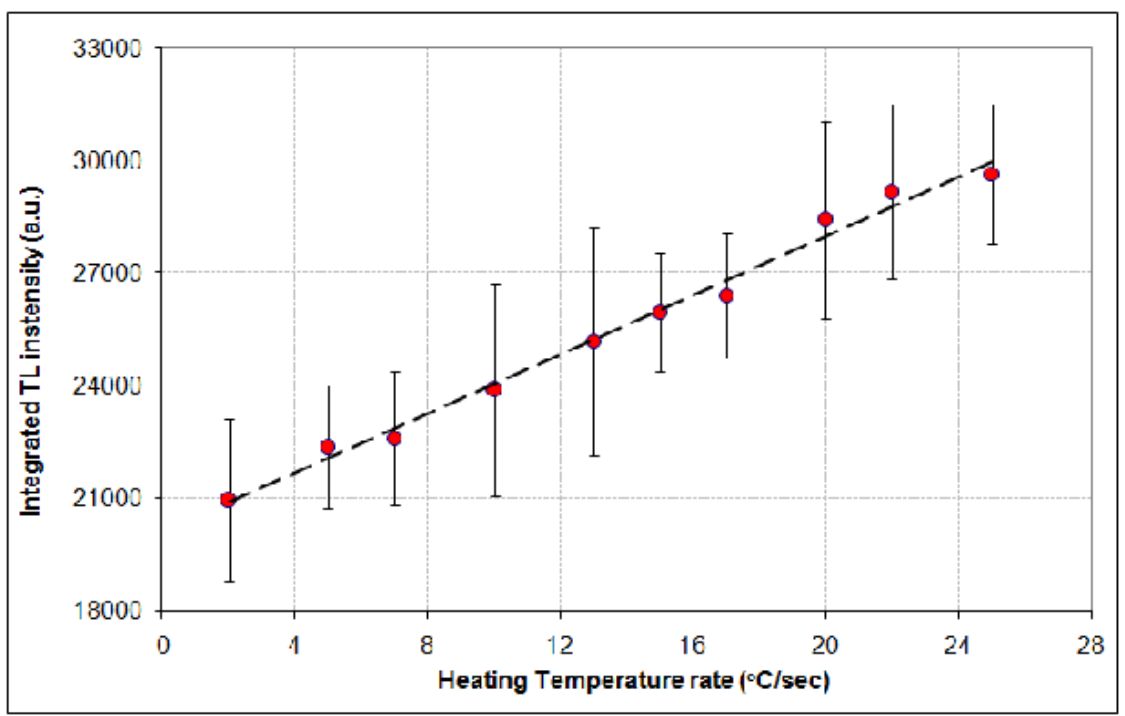

Figure (5) Integral TL intensity as a function of heating rate

\subsection{FADING}

In most TL materials the TL signal decreases as a function of storage time due to the thermal escape of trapped charge carriers and this characteristic is, therefore, usually referred to as 'thermally induced fading' or simply "fading". In this study, prepared LiF discs was irradiated, at a time, with $\gamma$-rays from a $\mathrm{Cs}^{137}$ source. For the anomalous-fading studies $\gamma$-dose of 50 Gy were examined.

TL fading was performed as follows: annealed chips were exposed to $\gamma$-doses (50Gy) and stored in the dark at room temperature. Successive measurements of the TL intensity of the chips were monitored over a period of 2 weeks. Figure (6) shows the integrated TL intensity as a function of elapsed time from the beginning of the irradiation. As shown, the integral TL intensity is reduced as the time proceeds and the reduction of the TL intensity as a function of time follows the mathematical formula

$$
y=A_{1} * \exp \left(-x / t_{1}\right)+A_{2} * \exp \left(-x / t_{2}\right)+y_{0}
$$

where y represents TL intensity (arbitrary units) and $\mathrm{x}$ is the elapsed time. Such formula is easily obtained by curve fitting. Table (1) shows the evaluated fitting parameters; $\mathrm{A}_{1}, \mathrm{~A}_{2}, \mathrm{t}_{1}, \mathrm{t}_{2}$ and $\mathrm{y}_{0}$ are fitting parameter; $\mathrm{y}_{0}$ represents the asymptotic TL integral intensity after fading process completed approximately after 2 weeks. Figure (7) show actual glow-curves of annealed LiF irradiated with gamma rays, stored in the dark for various selected times at room temperature. 


\begin{tabular}{|c||c|c|}
\hline Fitting parameter & Value & Standard Error \\
\hline \hline $\mathrm{y}_{0}$ & 14263.540 & 72.341 \\
\hline \hline $\mathrm{A}_{1}$ & 4913.228 & 274.741 \\
\hline \hline $\mathrm{t}_{1}$ & 61.954 & 5.867 \\
\hline \hline $\mathrm{A}_{2}$ & 2772.391 & 299.461 \\
\hline \hline $\mathrm{t}_{2}$ & 6.320 & 1.002 \\
\hline
\end{tabular}

Table (1) fading curve fitting parameter

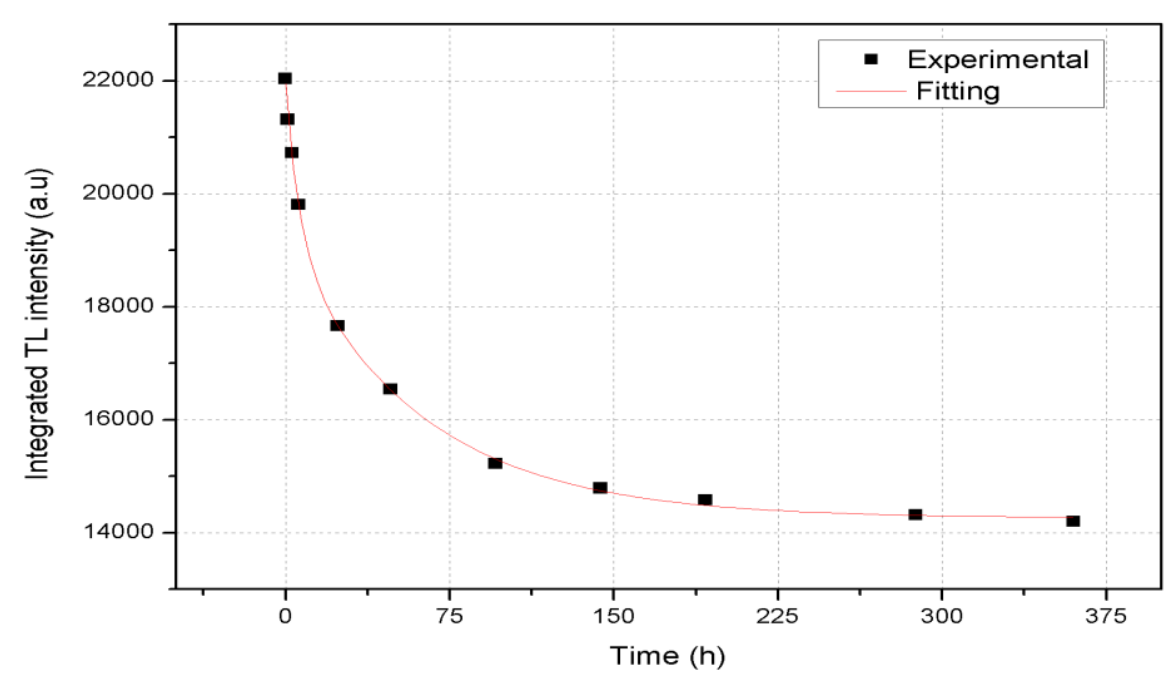

Figure (6): Decay curve of LiF were irradiated by ${ }^{60}$ Co source for $50 \mathrm{~Gy}$

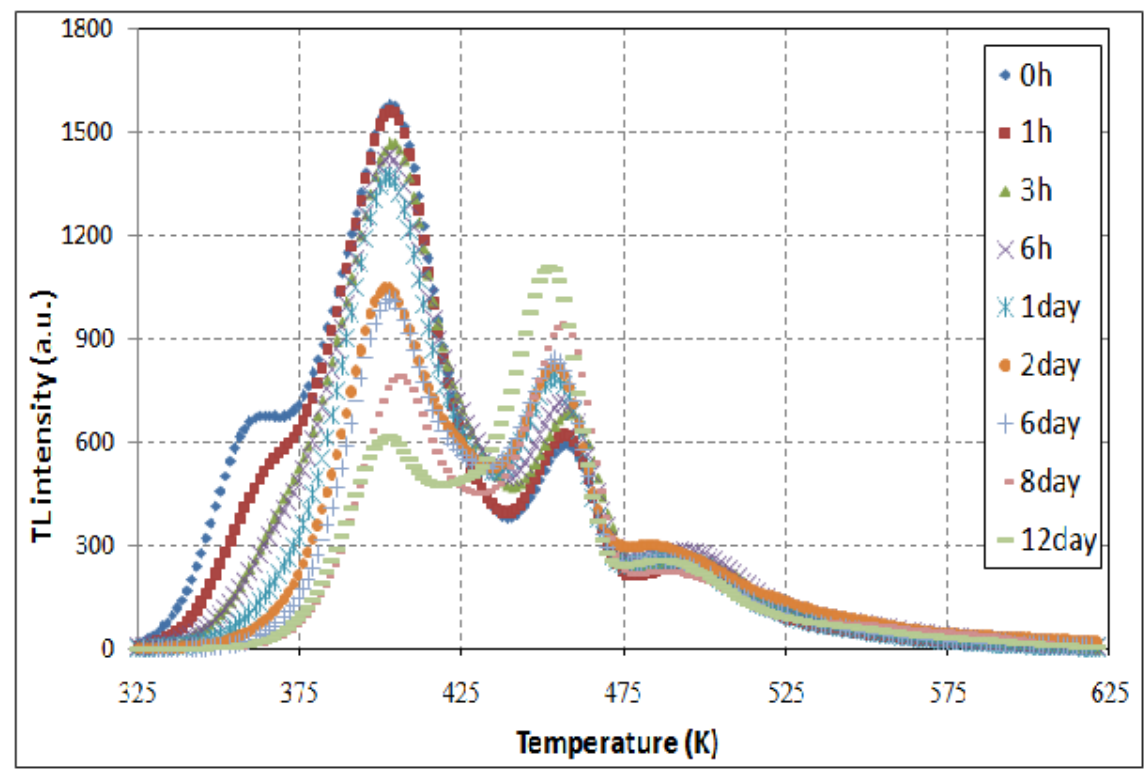

Figure (7) fading of LiF were irradiated by ${ }^{60}$ Co source for 50 Gy and stored at room temperature

From this figure it is apparent that the TL intensity decreased by time and has the same peak position; also we note that the shoulder glow peak at $360 \mathrm{~K}$ disappeared after 6 hour, the 
glow peak at $400 \mathrm{~K}$ decreases with time, the glow peak at $452 \mathrm{~K}$ increases with time and the glow peak at $485 \mathrm{~K}$ almost constant.

\section{Conclusion}

A $500 \mathrm{~nm} \mathrm{LiF}$ from Sigma-Aldrich has been ball milled for $1 \mathrm{~h}$ and the characterized using synchrotron XRD. The diffractogram has been analyzed by using $P M 2 K$ code and the analysis shows that the crystal size reduced to $37(8) \mathrm{nm}$ with dislocation density about $4.4(2) \times 10^{15} \mathrm{~m}^{-}$ 2 . The TL response of the annealed samples was investigated to study the effect of the dislocation on TL properties. When samples were irradiated at $50 \mathrm{~Gy}$, the observed glow curve has 4 prominent peaks at fixed positions at: $370,410,465,505^{\circ} \mathrm{K}$. Several discs have been measured at different heating rates, namely $2,5,7,10,13,15,17,20,22,25^{\circ} \mathrm{K} / \mathrm{sec}$. It has been found that the relation between heating rates and TL response is linear. At high heating rate, there is a lack between the real temperature of planchet and the temperature of the sample. This in turn leads to appearance of the glow peak at higher temperature than it should be. Worthy to mention that by using high heating rate the glow peaks are overlapped. For that reasons, the slowest heating rate is utilized for investigating the samples rather than the higher heating rates although higher heating rates give higher TL intensity. The optimum glow curve intensity is observed at a heating rate of $5 \mathrm{~K} / \mathrm{sec}$.

The dose-response is linear between 50Gy and $300 \mathrm{~Gy}$. The amplitudes of the aforementioned 4 prominent peaks increase as the dose increase; this may be explained by the expected change in defect concentration of $\mathrm{LiF}$ induced through irradiation.

For the fading studies, one $\gamma$-dose of 50Gy was examined. Successive measurements of the TL intensity from discs were monitored over a period of 12 days, which stored in the dark at room temperature. This study showed that the lower temperature peaks at $360 \mathrm{~K}$ are faded almost completely within 6 hours, the glow peak at $400 \mathrm{~K}$ decreases with time, the glow peak at $452 \mathrm{~K}$ increases with time and the glow peak at $485 \mathrm{~K}$ almost constant. This suggests that some of the photons emitted during fading from $2^{\text {nd }}$ glow peak are re-traped by traps responsible for the $3^{\text {rd }}$ peak. The overall integral TL intensity almost stabilizes after 12 day from first irradiation showing about $33 \%$ decrease without any further change in glow curve shape.

The results achieved in this study show that the micro structure changes induced by ball milling play important role in enhancing the TL response of LiF. Our results agreed with previous study (El Ashmawy et al.; 2016) in which the authors studied the effect of dislocations induced in $\mathrm{LiF}$ at different intervals of ball milling and they found that the TL 
response is significantly enhanced as the ball milling time increased up to certain limit $(20 \mathrm{~h})$ then the TL response decreased after this limit. They found that the dislocations play the major rule in affecting the TL response. Such study in parallel to our results presented in this paper open up new horizons in producing newly developed TL material without adding any kind of dopants. Although the prepared samples are not optimum from the point of view of TL dosimetry, however, the study confirms the proof of principle of using ball milling as an alternative for dopants to enhance the TL properties not only in LiF but also in other TL materials. So, efficient and easily prepared free of dopants TL dosimeter could be developed in near future.

\section{Acknowledgements}

The authors would like to acknowledge both the International Centre for Theoretical Physics (ICTP) and the Elettra synchrotron facility for offering access to the synchrotron radiation facility Elettra-Sincrotrone through the ICTP Elettra Users Program for carrying out the synchrotron in situ XRPD experiments at the MCX beam line.

\section{References}

Bacci, C., D'Angelo, L., Furetta, C., and Giancola, S. Comprehensive study on LiF: Cu, Mg, P (GR-200A), Radiat. Prot. Dosim., 47 (1-4), 215-218(1993).

Chandra, B., Lakshmanan, A. R., Bhatt, R. C. and Vohra, K. G. Annealing and Reusability characteristic of LiF (Mg, Cu, P) TLD phosphor, Radiat. Prot. Dosim. 3, 161-167 (1982).

Chen, R. and Mckeever, S.W.S., theory of thermoluminescence and related phenomena (Sngapore: World Scientific) Ch.4 (1997)

Daniels, F., in Luminescence Dosimetry, ed. By Attix. F.H., proc. First Int. Conf. Luminescence Dosimetry, US AEC, Div. Techn. Information Report Conf. 650637, p $34(\mathbf{1 9 6 5 )}$

DeWerd, L., Cameron, J., Da- Ke, W. Papini, T. and Das, I. Characteristics of a new dosimeter material: $\mathrm{LiF}$ (Mg, Cu, P), Radiat Prot Dosim, 6,350- 352(1984). 
El Ashmawy, M., Amer, H. \& Abdellatief, M.,. In situ synchrotron X-ray powder diffraction for studying the role of induced structural defects on the thermoluminescence mechanism of nanocrystalline LiF, J. Synchrotron Rad. 23, 501-509 (2016).

Kirsh, $\boldsymbol{Y}$. kinetic analysis of thermoluminescence theoretical and practical aspects, Phys. Status Solidi A, 129(1), 15- 48(1992).

Leoni, M., Confente, T.\& Scardi, P. PM2K: a flexible program implementing whole powder pattern modeling. Z. Kristallogr. Suppl 23:249-254(2006).

Nakajima, T., Murayama, Y., Matsuzawa, T. and Koyano, A., Development of a new highly sensitive LiF thermoluminescence dosimeter and its applications. Nucl. Instr. and Meth., $157,155-162(1978)$

Pradhan, $\boldsymbol{A}$. S. Influence of heating rate on the TL response of LiF TLD-700, LiF: $\mathrm{Mg}, \mathrm{Cu}, \mathrm{P}$ and AL203: Radiat Prot Dosim, 58 (1-4), 205-209(1995).

Rasheedy, M.S., and Amry, A.M.A. "The nonlinear response as a function of Irradiation, storage and thermal excitation of second order thermoluminescence signal", Nuclear Instruments and Methods in Physics Research A350, PP. 561-565(1994).

Rebuffi, L., Plaisier, J. R., Abdellatief, M., Lausi, A. \& Scardi, P. MCX: a synchrotron radiation beamline for X-ray diffraction line profile analysis. Z. Anorg. Allg. Chem. 640, 3100-3106 (2014).

Scardi, P. \& Leoni, M.. Acta Cryst. A58, 190-200(2002).

Scardi, P. \& Leoni, M. Whole Powder Pattern Modeling: Theory and Applications. Berlin: Springer Verlag (2004).

Vij, D.R. Thermoluminescent Material, Prentice-Hall, Englewood Cliffs NJ. (1993).

Wilkens, M. Fundamental Aspects of Dislocation Theory, edited by J. A. Simmons, R. de Wit and R. Bullough, Vol. II, pp. 1195-1221. National Bureau of Standards (US) Special Publication No. 317. Washington: National Bureau of Standards. (1970).

Wu, D. K., Sun, F. Y. and Dai, H. C. A high sensitivity LiF thermoluminescent dosimeter: LiF:Mg, Cu, P. Health Phys, 46 (5), 1063- 1067(1984). 


\section{الملخص باللغة العربية}

ملائمة إستخدام مادة الليثيوم فلورايد النانوية كمقياس وميض حرارى لجرعات أشعة جاما العالية هانى عامر، مصطقى العشماوى، هلى العزب، محمد رضا عز الدين

\section{قسم الوقاية الإثعاعية - هيئة الرقابة النووية والإشعاعية}

إن من أثهر المواد التى نستخدم فى قياس الجرعة الإشعاعية الثخصية مادة الليثيوم فلورايد لتكافؤها مع النسيج البشرى من حيث الكثافة. مادة الليثيوم فلورايد النقية محدودة الإستخدام فى قياس الإشعاعات المؤينة بسبب خلوها من المصايد بداخل تكوين هذه البلورات حيث تعتبر هذه المصايد هى المسئولة عن إحتفاظ البلورة بالإشعاع بداخلها حتى يتم تحريرها بالحرارة ولهذا لجأ العلماء إلى إضافة بعض المطعمات فى حدود جزء من المليون داخل هذه البلورة لتكوين هذه المصايد.

فى هذا البحث استخدمت طريقة أخرى حديثة لتكوين هذه المصايد عن طريق احداث عيوب فى البلورة بطحنها حيث ثم طحن بلورة الليثيوم فلورايد لمدة ساعة ثم نم ضغطها باستخدام المكبس إلى أقراص وحرقها لمدة ساعة عند 600 6 للتخلص من العيوب المتكونة عند درجات حرارة صغيرة. بعد عملية الطحن وعمل توصيف وقياس لهذه العينات باستخدام أثنعة السينكروترون بإيطاليا وجد أن حجم البلورات تتاقص إلى 50.4.4 50 جراى باستخدام مصدر كوبلت-60 . وبملاحظة منحنى الوميض الحرارى اتضح أن هناك أربع قمم رئيسية عند أماكن ثابتة وهى 370، 410، 465، 505 درجة مطلقة. وبدراسة تأثير معدل التسخين على البلورة عند 2، 5، 7، 10، 13، 15، 17، 20، 22 درجة مطلقة فى الثانية الواحدة لوحظ أن العلاقة طردية بين معدل التشخين والإستجابة. بدراسة مدى إستجابة البلورات للإثعاع وجد أنها تتاسب طرديا من 50 جراى حتى 300 جراى ، وبقياس قدرة هذه المادة على الإحتفاظ بالإشعاع فى ظروف التخزين العادية عند درجة حرارة الغرفة وجد حدوث ثبات فى معدل النقص بعد اثثا عثر يوما. 